\title{
School Heads' Leadership Practices in The New Normal, Administrative Disposition, and Readiness of The Public Schools in Laguna
}

\author{
Rycel B. Villar¹, Alberto D. Yazon², Consorcia S. Tan², Lerma P. Buenvinida², Marcial M. \\ Bandoy ${ }^{2}$ \\ ${ }^{1}$ Santa Rosa Elementary School Central III, Division of Santa Rosa City, DepEd IV-A, Philippines \\ ${ }^{2}$ College of Teacher Education, Laguna State Polytechnic University, Philippines
}

\begin{abstract}
School heads from the Philippines and around the globe are currently affronted by unexpected levels of adversities. They are facing threats, and which have been perennial to many, if not all, school organizations. This study assessed the relationship between the school heads' leadership practices, administrative disposition, and readiness of the public schools among school principals in the City Schools Divisions in Laguna for the school year 2020-2021. Two hundred five (205) public school principals were the respondents of the study. The researcher utilized the descriptive-correlational research design and self-made questionnaire to assess and measure the variables under study. The statistical tools used to analyze the data gathered were Mean, standard deviation, Pearson $r$ and Multiple Linear Regression Analysis. Findings revealed that the school heads' leadership practices and the administrative disposition were highly practiced during the new normal in the education system. In terms of the readiness of the public schools, the results revealed that the schools are much ready. The school heads' leadership practices and administrative disposition related the readiness of the school. The school heads' leadership practices in terms of resiliency in stress management and the administrative disposition in terms of inclusivity and accommodative significantly predicted the readiness of the public schools in the five City Schools Divisions in Laguna. This research contributed to the school's governance operations and contingency plan that will be used by the five city schools in the division of Laguna.
\end{abstract}

Keywords: School Heads' Leadership Practices, Administrative Disposition, New Normal, Readiness of the School

\section{This is an open-access article under the CC-BY-NC license.}

\section{INTRODUCTION}

The COVID-19 pandemic is causing havoc in the real world. It is wreaking havoc on the global economy, upheaving culture, and transforming education. COVID-19 has placed restrictions on the public sphere that would have been unimaginable just a few months earlier. It has unquestionably altered the educational landscape in the region. It is a difficult time for people from all walks of life. There are concerns and apprehensions. Most people are disturbed, and the uncertainties of the time have bothered their minds (WHO, 2020).

Furthermore, in the aftermath of the pandemic, education has been re-envisioned, re-designed, and relaunched as a home-based, technology-enabled online service (Harris, 2020). Teaching and learning methods have changed significantly, school roles have shifted, and education leaders have been stretched to their limits. Despite this, basic human services, especially education, cannot be suspended. It must go on to fulfill its role of educating the youth. 
International Journal of Theory and Application in Elementary and Secondary School Education (IJTAESE), Vol. 3 (2), 156-170

School Heads' Leadership Practices in The New Normal, Administrative Disposition, and Readiness of The Public Schools in Laguna

Rycel B. Villar, Alberto D. Yazon, Consorcia S. Tan, Lerma P. Buenvinida, Marcial M. Bandoy

\section{Internationally and globally, school leadership has become increasingly important in education. As mentioned by Tirozzi (2016), the principal of tomorrow's schools must be a school leader with the necessary expertise, capacities, and dedication to handle expanded responsibilities and lead the accountability parade. The prospects of institutional change in teaching and learning are slim without effective leadership. A commitment to effective leadership would help principals School Heads' Leadership Practices in The New Normal, Administrative Disposition, and Readiness of The Public Schools in Laguna}

\section{Rycel B. Villar¹, Alberto D. Yazon², Consorcia S. Tan², Lerma P. Buenvinida², Marcial M. Bandoy ${ }^{2}$}

adapt significantly to the changing circumstances. It has a significant impact on improving school outcomes by affecting school readiness, teacher motivation, and ability, as well as school climate and environment. To improve the quality and equity of education, effective school leadership is needed. During this pandemic, school leadership is a multifaceted position that faces challenges. In the Philippines, school administrators faced difficulties in transitioning from the old way of supervising schools to the new way. Most school leaders have built various leadership styles to help them prepare for this new educational normal. Unexpected and unavoidable levels of adversity are currently confronting school leaders in the Philippines and around the world. They face a variety of challenges and problems that have plagued many, if not all, school organizations for years. It may be due to aging and outdated school buildings, teacher morale problems, recruitment and selection issues, natural disasters, and the COVID-19 pandemic.

School leaders may have allowed themselves to be overcome by adversity, as has been observed. Farmer (2010) wrote about the "sustainability crisis" and the various challenges faced by school officials as they tried to sustain school reform efforts. He added the importance of interpersonal skills and teaching and learning skills for school leaders looking to continue school improvement efforts in urban and rural school settings

Commitment, empathy, tolerance, honesty, inclusivity, and accommodativeness were also identified as important qualities in administrative practice. Specific dispositions to look for in individuals aspiring to the principalship included "commitment to service, time commitment, and honesty" (Patrick, J. 2015). The management practices and managerial temperament of school principals must be the key to success in leading initiatives by establishing a common vision for the school community and implementing successful instructional processes that include teachers and stakeholders in decision-making.

According to The Philippines DepEd Memorandum No. 50, s. 2020 entitled DepEd Professional Development (PD) Priorities of Teachers and School Leaders for SY 2020 - 2023, the school leaders must undergo the different professional development in support of the operationalization of the school considering COVID-19. Here are the following Domains: 1. Leading Strategically; 2. Managing School Operations and Resources; 3. Focusing on Teaching and Learning; 4. Developing Self and Others; and 5. Building Connections.

The cited DepEd memorandum was very vital in the study. The study focused on the school leadership practices, administrative disposition, and readiness of the school. The findings of the study will help the school head to identify the relationship of their practices and disposition in the readiness of the school.

This study aimed to determine the relationship between the school heads' leadership practices in the new normal, administrative disposition, and readiness in the City Schools Division in Laguna for the school year 2020-2021.

Specifically, this study sought to answer the following questions:

1 What is the level of school heads' leadership practices?

2 What is the level of administrative disposition of the school head?

3 What is the level of readiness of the school?

4 Is there a significant relationship between the level of school heads' leadership practices and the readiness of the school? 
International Journal of Theory and Application in Elementary and Secondary School Education (IJTAESE), Vol. 3 (2), 156-170

School Heads' Leadership Practices in The New Normal, Administrative Disposition, and Readiness of The Public

$5 \quad$ Is there a significant relationship between the level of administrative disposition and the readiness of the school?

6 Do the school heads' leadership practices and administrative disposition significantly predict the readiness of the school?

7 Based on the results of the study, what school governance and operations contingency plan can be proposed?

\section{LITERATURE REVIEW}

In periods of adversity, good leaders can lead with their eyes wide open. Any politicians, on the other hand, are so risk-averse that they refuse to see the facts in dangerous circumstances. Others tend to be so cynical about every turn of events that they overlook prospects and development opportunities. But a leader who pays attention to relevant data recognizes both opportunities and harbingers of disaster. Such a leader monitors signals of flagging resilience in his or her organization and shores resilience up (Allison, 2016).

In research conducted by Cunningham and Cordeiro (2015), they believe that the "leader needs to be prepared to deal with the inevitable social, cultural, economic, technological, bureaucratic, and political obstacles that can block improvements efforts" (p. 137). On the contrary, Greenfield (2016) disagreed that an effective administration is not possible without efficient and effective leadership, and if school leadership is to be successful, it must deal with the five demands: moral, social, instructional, managerial, and political. Researchers concluded that effective schools hinge on the performance of the principal (Aitken, 2015).

Finally, Napire (2019) discussed in his study that the functions of the quality management skills of the principals' leadership practices are instructional directives, resiliency in stress management, management of conflicts, and establishing effective functional teams. The school leaders must practice these skills.

The present study is related to the study of Napire (2019) and Perez (2015), in which they both deal with the Management Practices and the Administrative Disposition of the School Head. The aim of this analysis was to gather information, analyze it, and address it in a way that would assist school principals and policymakers in developing new strategies and making appropriate decisions for the good of the school district and students. Henceforth, the researcher hoped that through the results of this study, the school principals and DepEd Officials might have additional knowledge and eventually bridge the identified gaps in the management aspects of the school being supervised.

\section{RESEARCH METHOD}

Descriptive correlational research was used in this study to test the relationship between the two dependent variables and the independent variable. This design was appropriate for the study since this determined the level of leadership practices of school heads, administrative disposition, and the readiness of the school.

The descriptive method was used to determine the leadership practices that are common among school heads in terms of: a. instructional directives; b. resiliency in stress management; c. management of conflicts; and d. establishing effective functional and administrative disposition and the school readiness as well. The correlational method was employed to determine the significant relationship between and among school heads' leadership practices, administrative disposition, and the readiness of the school in Laguna for SY 2020 - 2021.

The respondents of the study were the selected public elementary and secondary school heads in the City Schools Division of Laguna, including Binan, Santa Rosa, Cabuyao, Calamba, and San Pablo for the school year 2020 - 2021.

The researcher used Cochran's formula to determine the final number of respondents. The total number of public elementary and secondary school heads in the five (5) City Divisions was 247. Using the formula for sampling determination of schools, 225 schools were considered in this study. After determining 
International Journal of Theory and Application in Elementary and Secondary School Education (IJTAESE), Vol. 3 (2), 156-170

School Heads' Leadership Practices in The New Normal, Administrative Disposition, and Readiness of The Public

Schools in Laguna

Rycel B. Villar, Alberto D. Yazon, Consorcia S. Tan, Lerma P. Buenvinida, Marcial M. Bandoy

the number of schools, 225 out of 247 public elementary and secondary school heads were the final respondents of this study. However, only 205 school heads, or $91 \%$ of the total target respondents, responded and were included in the study after the data collection process.

The researcher utilized the stratified random sampling technique in determining the respondents. The researcher used the sample size calculator with a $2 \%$ margin of error to determine the sample size to be used in the stratified sample technique. As to its population, this study involved the school heads from the public elementary and secondary schools in the City Schools Division of Laguna. Out of 247 school heads in the City Schools Divisions of Laguna, 225 were the respondents based on the result of the stratified sampling technique. However, there were 205 school heads who answered the questionnaire.

Independent Variables

Dependent Variables

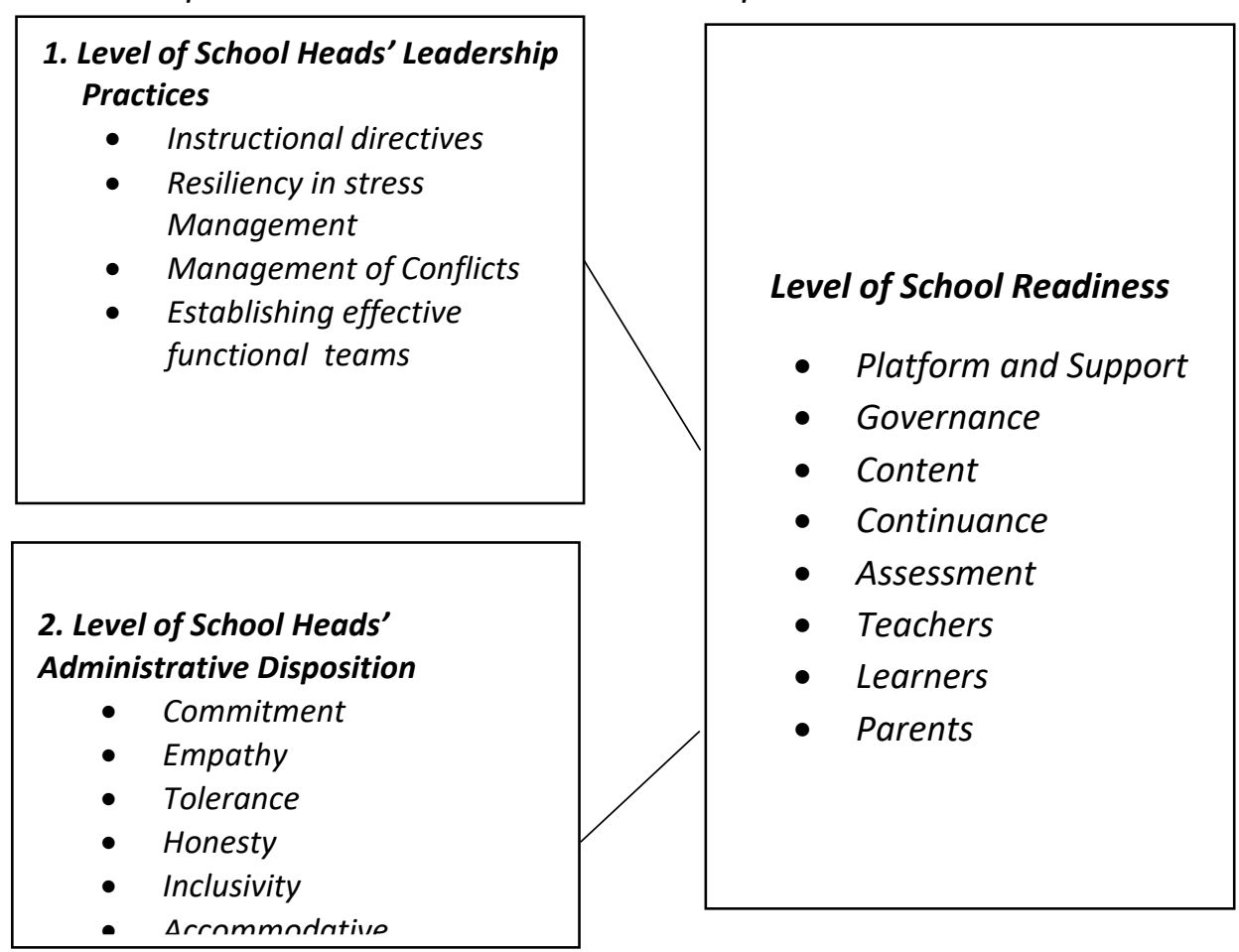

Figure 1. Research Paradigm of the Study IV-DV

Figure 1 shows the Research Paradigm of the Study, which are the independent and dependent variables. Independent variable comprises School heads' Leadership Practices in terms of Instructional directives, Resiliency in stress management, Management of Conflicts, and Establishing effective functional teams and the Administrative Disposition such as commitment, empathy, tolerance, honesty, inclusivity, and accommodative. Dependent variable includes the School Readiness in terms of Platform and support, Governance, Content, Continuance, Assessment, Teachers, Learners, and Parents. The line in the middle of the boxes represents the relationship between the given variables. This is guided by the assumption that the higher level of school heads' leadership practices and administrative disposition, the higher the level of their school readiness.

In addition, School Heads' Leadership Practices (SLPQ) is an instrument designed to measure the school heads' leadership practices in the new normal. This is a 20- point self-assessment Questionnaire guided by the concept of Napire (2019) entitled "Adversity Quotient and Management Skills of School Principals: Their Influence on Institutional Performance" while the Administrative Disposition Questionnaire (ADQ) is 
International Journal of Theory and Application in Elementary and Secondary School Education (IJTAESE), Vol. 3 (2), 156-170

School Heads' Leadership Practices in The New Normal, Administrative Disposition, and Readiness of The Public

Schools in Laguna

Rycel B. Villar, Alberto D. Yazon, Consorcia S. Tan, Lerma P. Buenvinida, Marcial M. Bandoy

an instrument designed to measure the administrative disposition of the school in the new normal. This is guided by the study of Perez, Oyugi (2015) entitled, "Knowledge, Skills, and Dispositions of School Principals: Perspectives from Kisumu County, Kenya." Moreover, Readiness of the School Questionnaire (SLPQ). An instrument designed to measure the readiness of the school in the new normal. This is guided by the DepEd order no. 13, s.2020, LDM Course 1 for School Principal Module 3 and 4, and Ogena et al. (2020) entitled, "Education Imperative for the New Normal Planning for Flexible Learning.

The main instrument used in this study was a set of questionnaires. A researcher-made questionnaire was utilized. Respondents were given a set of questionnaires for them to answer the school heads' leadership practices, administrative disposition, and the school readiness. The survey questionnaire was divided into two parts. The first part includes the information of the respondents. The second part includes the questions about school heads' leadership practices, administrative disposition, and school readiness.

The questionnaire was checked and validated by the experts in the field of Education and pilot-tested with a group of school heads who were not part of the respondents. The researcher used the 6-point Likert scale for easy administration and scoring of the questionnaire.

The results show that the reliability of the instrument was excellent since it had a Cronbach Alpha Coefficient of .954 (See annex C). According to Mohammad (2015), reliability values close to 1.00 indicated that the investigated factors could be measured. Therefore, the instrument made by the researcher can be measured based on the results of the pilot testing.

A communication letter was submitted to the School's Division Superintendent of the five (5) City schools in Laguna. After the approval of the letter, the researcher forwarded the approved letter to the schools. Upon approval, the researcher administered the adopted questionnaire to the respondents.

The study was carried out in the school. The respondents were informed before the collection of the data using the permission letters containing important information about this research and the importance of their participation in the study. The aim was to seek their consent, ensure voluntary participation and provision of information, as well as give them free room to withdraw from the research participation any time they wished. Furthermore, the schools and participants in the entire study were kept anonymous. The respondents were given a letter for the approval of their participation, and ethical consideration was practiced. The data gathering was started last April 12, 2021 and ended last May 3, 2021. There is almost one month duration for data gathering.

Additionally, the data collected from the respondents were kept confidential and were erased after its use. The researcher used Google Forms for the survey questionnaire and sent the link to the respondents. The responses were downloaded through excel form. After the survey data collection of the instruments, the results were tallied, analyzed, and interpreted using appropriate statistical treatment. The SPSS or the Statistical Package for the Social Sciences was used to identify the results from the respondents' answers.

To answer the stated problems of the study, the data were subjected to the following statistical treatment. Weighted mean and standard deviation were used to determine the school heads' leadership practices, administrative disposition, and readiness of the school. Pearson Product Moment of Correlation was used to determine the relationship between School heads' leadership practices and Administrative Disposition, and School Readiness. Finally, Multiple Linear Regression was used to determine the significant predictors of the school heads' leadership practices and Administrative Disposition on the School Readiness.

\section{FINDINGS AND DISCUSSION}

The data gathered by the researcher, which had been presented, analyzed, and interpreted, revealed the level of school heads' leadership practices, administrative disposition, and readiness of the public school. Table 1 shows the level of school heads' leadership practices in terms of instructional directives.

Table 1. Level of school heads' leadership practices in terms of instructional directives

\begin{tabular}{lllll}
\hline Indicative Statement & Mean & SD & $\begin{array}{c}\text { Scaled } \\
\text { Response }\end{array}$ & Rank \\
\hline
\end{tabular}


International Journal of Theory and Application in Elementary and Secondary School Education (IJTAESE), Vol. 3 (2), 156-170 School Heads' Leadership Practices in The New Normal, Administrative Disposition, and Readiness of The Public Schools in Laguna

Rycel B. Villar, Alberto D. Yazon, Consorcia S. Tan, Lerma P. Buenvinida, Marcial M. Bandoy

1. Being considerate with subordinates when instructing them and working with subordinates to change content and instructional methods if not applicable.

2. Encouraging engagement of subordinates as appropriately needed and eliminating barriers to establish high expectations.

3. Being responsive to subordinate's needs rather than just own point of view in designing school's organization to enhance the teaching and learning.

4. Taking responsibility for the decisions rather than blaming others.

\begin{tabular}{|c|c|c|c|}
\hline 5.92 & 0.31 & $\begin{array}{c}\text { Highly } \\
\text { Practiced }\end{array}$ & 1 \\
\hline 5.88 & 0.34 & $\begin{array}{c}\text { Highly } \\
\text { Practiced }\end{array}$ & 2 \\
\hline 5.84 & 0.45 & $\begin{array}{c}\text { Highly } \\
\text { Practiced }\end{array}$ & 3 \\
\hline 5.83 & 0.46 & $\begin{array}{c}\text { Highly } \\
\text { Practiced }\end{array}$ & 4 \\
\hline 5.82 & 0.48 & $\begin{array}{c}\text { Highly } \\
\text { Practiced }\end{array}$ & 5 \\
\hline 5.86 & 0.30 & $\begin{array}{c}\text { Highly } \\
\text { Practiced }\end{array}$ & \\
\hline
\end{tabular}

Legend: 5.50-6.00 Highly Practiced; 4.50-5.49 Practiced; 3.50-4.49 Mostly Practiced; 2.50-3.49 Rarely Practiced; 1.50-2.49; Least Practiced; $1.00-1.49$ Not Practiced

Table 2 shows the level of school heads' leadership practices in terms of establishing effective functional teams. It could be observed from the table that "Encouraging group participation in making decisions like involving the Master Teachers, Head Teachers, and the Grade Level Chairman" received the highest rating of (5.84), interpreted as highly practiced, followed by "Allowing the subordinates to innovate and promote continuous improvement for the school" (5.77) interpreted as highly practiced while "Utilizing the different ways to develop a strong relationship among subordinates" received the lowest overall mean of 5.70 interpreted as highly practiced. The overall mean was 5.75 indicated as highly practiced by the school heads.

Based on the gathered data, instructional directives and establishing effective and functional teams are the top 2 school heads' leadership practices that are highly practiced by the school head-respondents. All the sub-indicators of the instructional directives, resiliency in stress management, management of conflicts, and establishing effective and functional teams were highly practiced by the respondents.

Table 2. Level of school heads' leadership practices in terms of establishing effective functional teams

\begin{tabular}{|c|c|c|c|c|}
\hline Indicative Statement & Mean & $S D$ & $\begin{array}{c}\text { Scaled } \\
\text { Response }\end{array}$ & Rank \\
\hline $\begin{array}{l}\text { 1. Encouraging group participation in } \\
\text { making decisions like involving the } \\
\text { Master Teachers, Head Teachers, and the } \\
\text { Grade Level Chairman. }\end{array}$ & 5.84 & 0.43 & $\begin{array}{c}\text { Highly } \\
\text { Practiced }\end{array}$ & 1 \\
\hline $\begin{array}{l}\text { 2. Allowing the subordinates to innovate } \\
\text { and promote continuous improvement } \\
\text { for the school. }\end{array}$ & 5.77 & 0.51 & $\begin{array}{c}\text { Highly } \\
\text { Practiced }\end{array}$ & 2 \\
\hline $\begin{array}{l}\text { 3. Providing a clear and motivational } \\
\text { mission that is anchored to DepEd } \\
\text { mission and vision to achieve its goal. }\end{array}$ & 5.72 & 0.51 & $\begin{array}{c}\text { Highly } \\
\text { Practiced }\end{array}$ & 4 \\
\hline
\end{tabular}


International Journal of Theory and Application in Elementary and Secondary School Education (IJTAESE), Vol. 3 (2), 156-170

School Heads' Leadership Practices in The New Normal, Administrative Disposition, and Readiness of The Public

Schools in Laguna

Rycel B. Villar, Alberto D. Yazon, Consorcia S. Tan, Lerma P. Buenvinida, Marcial M. Bandoy

4. Utilizing the different ways to develop a strong relationship among subordinates.

5.70 $\quad 0.57 \quad$ Highly

Practiced

5

5. Developing a harmonious relationship with subordinates before, during, and 5.74 $0.55 \quad$ Highly

Practiced

after accomplishing the given tasks.

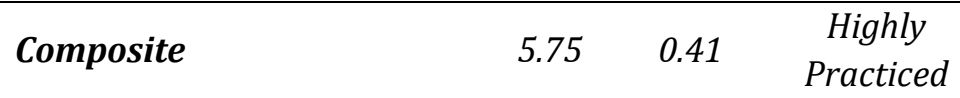

Legend: 5.50-6.00 Highly Practiced; 4.50-5.49 Practiced; 3.50-4.49 Mostly Practiced; 2.50-3.49 Rarely Practiced; 1.50-2.49; Least Practiced; 1.00-1.49 Not Practiced

In terms of instructional directives, the attained average mean is 5.71 interpreted as highly practiced. Similarly, in terms of resiliency in stress management, a composite mean of 5.71 is interpreted as highly practiced. Moreover, in terms of management of conflicts, under this feature, the overall mean (5.72) was viewed as highly practiced by the school heads. In addition, the overall mean was 5.75 indicated as highly practiced in terms of establishing effective functional teams. Table 3 shows the Level of school heads' administrative disposition in terms of commitment.

Table 3. Level of school heads' administrative disposition in terms of commitment

\begin{tabular}{|c|c|c|c|c|}
\hline Indicative Statement & Mean & $S D$ & $\begin{array}{c}\text { Scaled } \\
\text { Response }\end{array}$ & Rank \\
\hline $\begin{array}{l}\text { 1. I recommend this organization to my family } \\
\text { and friends. }\end{array}$ & 5.64 & 0.61 & Very Evident & 2 \\
\hline $\begin{array}{l}\text { 2. I am willing to put in a great deal of extra } \\
\text { effort to help this organization be successful. }\end{array}$ & 5.70 & 0.50 & Very Evident & 1 \\
\hline $\begin{array}{l}\text { 3. I am encouraged to be creative and } \\
\text { innovative to meet the needs of the } \\
\text { stakeholders. }\end{array}$ & 5.62 & 0.58 & Very Evident & 3 \\
\hline 4. I live for my job. & 5.32 & 0.89 & Evident & 5 \\
\hline $\begin{array}{l}\text { 5. I feel the level of responsibility I am given is } \\
\text { acceptable. }\end{array}$ & 5.60 & 0.61 & Very Evident & 4 \\
\hline Composite & 5.57 & 0.44 & Very Evident & \\
\hline
\end{tabular}

Legend: 5.50-6.00 Very Evident; 4.50-5.49 Evident; 3.50-4.49 Almost Evident; 2.50-3.49; Quite Evident; 1.50-2.49 Less Evident; 1.00-1.49 Not Evident

Table 4 shows the level of school heads' administrative disposition in terms of empathy.

Table 4. Level of school heads' administrative disposition in terms of empathy

\begin{tabular}{|c|c|c|c|c|}
\hline Indicative Statement & Mean & $S D$ & $\begin{array}{c}\text { Scaled } \\
\text { Response }\end{array}$ & Rank \\
\hline $\begin{array}{l}\text { 1. I get a strong urge when someone in my } \\
\text { subordinates is upset. }\end{array}$ & 5.12 & 1.17 & Evident & 3 \\
\hline $\begin{array}{l}\text { 2. I am really interested in the feelings of my } \\
\text { subordinates. }\end{array}$ & 3.94 & 1.96 & Almost Evident & 5 \\
\hline
\end{tabular}


International Journal of Theory and Application in Elementary and Secondary School Education (IJTAESE), Vol. 3 (2), 156-170

School Heads' Leadership Practices in The New Normal, Administrative Disposition, and Readiness of The Public

Schools in Laguna

Rycel B. Villar, Alberto D. Yazon, Consorcia S. Tan, Lerma P. Buenvinida, Marcial M. Bandoy

\begin{tabular}{lccccc}
\hline 3. $\begin{array}{l}\text { I have tender, concerned feelings for my } \\
\text { subordinates, especially when they are } \\
\text { sad. }\end{array}$ & 5.39 & 0.82 & Evident & 2 \\
$\begin{array}{l}\text { 4. } \begin{array}{l}\text { It upsets me to see someone being treated } \\
\text { disrespectfully. }\end{array} \\
\quad 5.42\end{array}$ & 0.79 & Evident & 1 \\
$\begin{array}{l}\text { I feel motivated when my subordinate is } \\
\text { happy. }\end{array}$ & 4.24 & 1.81 & Almost Evident & 4 \\
\hline \hline
\end{tabular}

Legend: 5.50-6.00 Very Evident; 4.50-5.49 Evident; 3.50-4.49 Almost Evident; 2.50-3.49; Quite Evident; 1.50-2.49 Less Evident; 1.00-1.49 Not Evident

It could be seen from the table that the indicative statement number 4, which states that "It upsets me to see someone being treated disrespectfully," yielded a mean of 5.42, which denoted an evident rank first. This is followed by the indicative statement number 3 with a mean of 5.39 and an evident scaled response. However, indicative statement number 2, which states that "I am really interested in the feelings of my subordinates," yielded a mean of 3.94 denoted as almost evident ranked lowest. Based on the findings, the level of school heads' administrative dispositive in terms of empathy is evident, which has an overall mean of 4.82 .

The administrative disposition of the respondents in terms of commitment, honesty, inclusivity, and accommodative was very evident, while empathy and tolerance were evident. The overall mean of the administrative disposition of the school head in terms of commitment was 5.57 denoted as very evident. Likewise, in terms of empathy, the attained mean 4.82 was interpreted as evident. In terms of tolerance, the overall mean was 5.38 and interpreted as evident. The overall mean of 5.62 suggested that the school heads' administrative disposition in terms of honesty is very evident. Based on the findings of the study, the overall mean was 5.51 interpreted as very evident when it comes to inclusivity. Meanwhile, the composite mean of 5.17 denoted as very evident, was the result in terms of accommodative. Table 5 shows the level of readiness of the school in terms of platform and support.

Table 5. Level of readiness of the school in terms of platform and support

\begin{tabular}{|c|c|c|c|c|}
\hline Indicative Statement & Mean & $S D$ & $\begin{array}{c}\text { Scaled } \\
\text { Response }\end{array}$ & Rank \\
\hline $\begin{array}{l}\text { 1. The school has an educational platform } \\
\text { or Learning Management System (LMS), } \\
\text { either subscription-based or locally } \\
\text { developed. }\end{array}$ & 5.32 & 1.02 & Much Ready & 2 \\
\hline $\begin{array}{l}\text { 2. Does the school have the technical } \\
\text { expertise to run and support the } \\
\text { educational platform 24/7? Note: } \\
\text { Technical expertise can be in-house OR } \\
\text { outsourced OR a combination, depending } \\
\text { on the nature of the deployment. The } \\
\text { more IN-HOUSE/locally developed is the } \\
\text { hosted platform, the higher the degree of } \\
\text { the technical support personnel required. }\end{array}$ & 5.05 & 1.10 & Much Ready & 4 \\
\hline $\begin{array}{l}\text { 3. The school has an email facility or } \\
\text { domain name for all teachers and users. }\end{array}$ & 5.44 & 0.84 & Much Ready & 1 \\
\hline $\begin{array}{l}\text { 4. The learners have or can be provided an } \\
\text { official email account by your school. }\end{array}$ & 5.03 & 1.20 & Much Ready & 5 \\
\hline
\end{tabular}


International Journal of Theory and Application in Elementary and Secondary School Education (IJTAESE), Vol. 3 (2), 156-170

School Heads' Leadership Practices in The New Normal, Administrative Disposition, and Readiness of The Public

Rycel B. Villar, Alberto D. Yazon, Consorcia S. Tan, Lerma P. Buenvinida, Marcial M. Bandoy

5. The school has helpdesk personnel working under the platform managers whose main task will be to directly $5.19 \quad 1.02 \quad$ Much Ready $\quad 3$ answer usage queries of both teachers and students.

$\begin{array}{llll}\text { Composite } & 5.20 & 0.81 & \text { Much Ready }\end{array}$

Legend: 5.50-6.00 Very Much Ready; 4.50-5.49 Much Ready; 3.50-4.49 Almost Ready; 2.50-3.49; Quite Ready; 1.50-2.49 Less Ready; 1.00-1.49 Not Ready

It can be seen from the results that "The school has email facility or domain name for all teachers and users" yielded the highest mean of 5.44 denoted as much ready ranked first. However, the indicative statement "The learners have or can be provided an official email account by your school" with the lowest mean of 5.03 denoted as much ready was last in rank. Based on the findings, it appeared that the overall mean is 5.20, which explained that the level of readiness of the public schools in terms of platform and support is much ready.

The readiness of the school in terms of governance, content, assessment, and teacher's preparedness was very much ready, while platform and support, continuance, learner's preparedness, and parent's preparedness are much ready. Based on the findings, it appeared that the overall mean is 5.20 denoted as much ready in terms of platform and support. Likewise, in terms of governance, the obtained overall mean of 5.50 indicates very much ready. The attained average mean in the content is 5.50, which denoted that the school was very much ready. Similarly, in terms of continuance, there was an overall mean of 5.27 interpreted as much ready.

Meanwhile, the overall mean of 5.47 indicated that the school was very much ready when it came to assessment. It can be inferred from the overall mean of 5.52 that the school was very much ready in terms of teachers' preparedness. However, the overall mean of 5.09 denoted that the level of readiness of the school in terms of learner's preparedness was much ready. In addition, it appeared on the table that the overall mean of 5.09 denoted that the level of readiness of the school in terms of teacher's preparedness was much ready.

Table 6 shows the test of the significant relationship between the level of school heads' leadership practices and the readiness of the school.

It could be inferred that the school heads' leadership practices in terms of instructional directives is highly significant along with governance (.184), and it is significant along with teacher preparedness (.149) at .01 levels.

However, the school heads' leadership practices in terms of resiliency in stress management is highly significant along with platform and support (.270), governance (.207), continuance (.241), teacher preparedness (.254), and learner preparedness (.241) and significant along with content (.142) and parent preparedness (.163) at .01 levels.

Table 6. Test of significant relationship between the level of school heads' practices and the readiness of the school

\section{School Head's Practices}

\begin{tabular}{lllll}
\cline { 2 - 5 } Readiness of the School & & Resiliency in & Management \\
& Instructional & $\begin{array}{l}\text { Establishing } \\
\text { Effective } \\
\text { Management }\end{array}$ & $\begin{array}{l}\text { of Conflicts } \\
\text { Functional } \\
\text { teams }\end{array}$ \\
& & & .030 & .086
\end{tabular}


International Journal of Theory and Application in Elementary and Secondary School Education (IJTAESE), Vol. 3 (2), 156-170

School Heads' Leadership Practices in The New Normal, Administrative Disposition, and Readiness of The Public Schools in Laguna

Rycel B. Villar, Alberto D. Yazon, Consorcia S. Tan, Lerma P. Buenvinida, Marcial M. Bandoy

\begin{tabular}{lllll}
\hline Governance & $.184^{* *}$ & $.207^{* *}$ & $.340^{* *}$ & $.321^{* *}$ \\
Content & .077 & $.142^{*}$ & $.208^{* *}$ & $.222^{* *}$ \\
Continuance & .040 & $.241^{* *}$ & .017 & $.150^{*}$ \\
Assessment &. .010 & .073 & .039 & .085 \\
Teacher Preparedness & $.149^{*}$ & $.254^{* *}$ & $.179^{*}$ & $.313^{* *}$ \\
Learner Preparedness & -.012 & $.241^{* *}$ & .031 & .019 \\
Parent Preparedness & .026 & $.163^{*}$ & .117 & .021
\end{tabular}

**Correlation is significant at .01 level (2-tailed)

${ }^{*}$ Correlation is significant at .05 level (2-tailed)

Table 7 shows the test of significant relationship between the level of school heads' administrative disposition and the readiness of the school.

Table 7. Test of significant relationship between the level of school heads' administrative disposition and the readiness of the school

\section{School Head's Administrative Disposition}

Readiness of the

School

Commitment Empathy Tolerance Honesty

Inclusivity Accommodative

\begin{tabular}{lllllll}
\hline \hline $\begin{array}{l}\text { Platform and } \\
\text { Support }\end{array}$ & $.199^{* *}$ & $.143^{*}$ & $.230^{* *}$ & .095 & $.158^{*}$ & $.311^{* *}$ \\
Governance & $.340^{* *}$ &. .048 & .124 & $.269^{* *}$ & $.344^{* *}$ & .089 \\
Content & $.183^{* *}$ & .085 & .111 & $.227^{* *}$ & $.300^{* *}$ & $.221^{* *}$ \\
Continuance & $.207^{* *}$ & $.222^{* *}$ & $.213^{* *}$ & $.148^{*}$ & $.274^{* *}$ & $.332^{* *}$ \\
Assessment & .091 & .031 & .120 & .083 & $.197^{* *}$ & .111 \\
$\begin{array}{l}\text { Teacher } \\
\text { Preparedness }\end{array}$ & $.363^{* *}$ & .097 & $.143^{*}$ & $.257^{* *}$ & $.382^{* *}$ & $.212^{* *}$ \\
$\begin{array}{l}\text { Learner } \\
\text { Preparedness }\end{array}$ & $.205^{* *}$ & $.438^{* *}$ & $.358^{* *}$ & .090 & $.226^{* *}$ & $.422^{* *}$ \\
$\begin{array}{l}\text { Parent } \\
\text { Preparedness }\end{array}$ & $.150^{*}$ & $.202^{* *}$ & $.253^{* *}$ & .019 & $.313^{* *}$ & $.273^{* *}$ \\
\hline
\end{tabular}

**Correlation is significant at .01 level (2-tailed)

${ }^{*}$ Correlation is significant at .05 level (2-tailed) 
International Journal of Theory and Application in Elementary and Secondary School Education (IJTAESE), Vol. 3 (2), 156-170

School Heads' Leadership Practices in The New Normal, Administrative Disposition, and Readiness of The Public

Table 7 presents the correlation results between the level of school heads' administrative disposition and readiness of the school.

The school heads' leadership practices are significant in the readiness of the school. Likewise, the administrative disposition was significant in the readiness of the school. The multiple regression analysis revealed that Inclusivity and Accommodative (Disposition) and Resilience in Stress Management (School Head's Practices) contributed significantly to the regression model $F(3,200)=26.419, \mathrm{p}<.01$ and accounted for $53.3 \%$ of the variation in School's Readiness scores. Inclusivity, accommodative, and resilience in stress management significantly predict the school's readiness.

Table 8. Test of significant prediction of school heads' leadership practices and administrative disposition on the readiness of the school

\begin{tabular}{|c|c|c|c|c|c|c|}
\hline \multirow[b]{2}{*}{ Model } & \multirow[b]{2}{*}{ Predictors } & \multicolumn{2}{|c|}{ Unstandardized Coefficients } & \multirow{2}{*}{$\begin{array}{c}\text { Standardized } \\
\text { Coefficients } \\
\text { Beta }\end{array}$} & \multirow[t]{2}{*}{$t$} & \multirow[t]{2}{*}{ Sig. } \\
\hline & & $B$ & Std. Error & & & \\
\hline \multirow{4}{*}{1} & (Constant) & 1.588 & .463 & & 3.428 & .001 \\
\hline & Inclusivity & .224 & .060 & .248 & 3.735 & .000 \\
\hline & Accommodative & .185 & .044 & .277 & 4.231 & .000 \\
\hline & $\begin{array}{l}\text { Resiliency in } \\
\text { Stress } \\
\text { Management }\end{array}$ & .276 & .069 & .242 & 3.980 & .000 \\
\hline
\end{tabular}

Adj R2 = 53.3\%; F $(3,200)=26.419 ; p<0.01 ; \mathrm{N}=204$

School Readiness

Table 8 shows the test of the significant prediction of school heads' leadership practices and administrative disposition on the readiness of the school. A stepwise multiple linear regression was conducted with school readiness as the dependent variable and the four (4) constructs of school head's practices and six (6) dimensions of administrative disposition as independent variables. The multiple regression analysis revealed that Inclusivity and Accommodative (Disposition) and Resilience in Stress Management (School Head's Practices) contributed significantly to the regression model F $(3,200)=26.419$, $\mathrm{p}<.01$ and accounted for $53.3 \%$ of the variation in School's Readiness scores. Hence, the model suggests that the inclusivity, accommodative, and resilience in stress management significantly predict the school's readiness which yields the final regression:

\section{$S R=.224 I+.185 A+.276 R S M+1.588$}

where $\mathrm{SR}=$ School Readiness score;

I = Inclusivity;

A = Accommodative;

RSM = Resilience in Stress Management

\section{DISCUSSIONS}

The level of school heads' leadership practices in terms of instructional directives is interpreted as highly practiced. This aspect plays an important role in leadership to ensure communication of the school goals and objectives are clearly defined and acquainted subordinates of the road map of the institution to positively achieve school performance. It can be seen from the results that "Being considerate with subordinates when instructing them and work with subordinates to change content and instructional methods if not applicable" yielded a mean of 5.92 interpreted as highly practiced, which ranked as number 1 . "Encouraging engagement of subordinates as appropriately needed and eliminating barriers to establish high 
International Journal of Theory and Application in Elementary and Secondary School Education (IJTAESE), Vol. 3 (2), 156-170

School Heads' Leadership Practices in The New Normal, Administrative Disposition, and Readiness of The Public

Schools in Laguna

Rycel B. Villar, Alberto D. Yazon, Consorcia S. Tan, Lerma P. Buenvinida, Marcial M. Bandoy

expectations" (5.88) ranked second, while "Devoting time to identify an area of agreement on school issues with subordinates with a different opinion to promote open communication" (5.82) last in rank. As reflected in the table, the overall mean along instructional directives was 5.86 , which means it was highly practiced by the school heads.

When it came to instructional directives, the results showed that school leaders gave their subordinates a lot of thought. The smooth implementation of school programs and projects was linked to open and direct communication among school staff. It also increased teachers', students', and stakeholders' confidence in school leaders, who promoted greater emphasis on the importance of accountability, shared leadership, and governance. In all of their roles and duties, a good principal retained a sense of balance to ensure that they were doing what they felt was best for all of their constituents (Meador, 2017).

However, in terms of establishing effective functional teams, the school heads' leadership practices were highly practiced. An overall mean of 5.75 obtained along establishing effective functional teams was an indication of the highly practiced school heads' leadership practices in seeking the participation of the subordinates and community to actively support school endeavors for the betterment of its performance. The findings may be due to school principals' promotion of group involvement in decision-making processes, as well as their subordinates' willingness to innovate and foster continuous development in their schools. The position of school principals has been critical in motivating teachers to be productive and attentive to their student's academic success.

According to the findings of Calleja (2014), three criteria are important in predicting perceived team effectiveness: team member competency, effective leadership, and relationship quality, which differs significantly from previous Western team effectiveness models. These findings support the idea that national culture has an impact on the dynamics and outcomes of workgroups.

Moreover, the level of the school head's administrative disposition in terms of commitment was evident. The overall mean of the administrative disposition of the school head in terms of commitment is 5.57, which is denoted as very evident. Committed workers, according to Madigan, Norton, and Testa (2002), would function tirelessly and conscientiously, provide value, support the company's services or goods, and strive for quality improvement. In return, they expect a work environment that promotes development and empowerment, allows for a better balance of personal and professional lives, offers the required tools to meet consumer needs, and supports their own and their coworkers' education and training.

According to the findings of Ingay (2018), the level of leadership practice among school heads is extremely high; the level of job commitment among school heads is also very high; and the level of teacher morale is also extremely high. There is a substantial association between school heads' leadership practices and teachers' morale; there is also a substantial association between school heads' working dedication and teachers' morale.

It also agrees with Egley and Jones (2005) that the principal's commitment to their work has an impact on teacher morale. A principal who focuses on compassion and respect for the teachers through collaboration and mutual respect has a disciplined working performance and commitment.

However, in terms of the level of the readiness of the school, it appeared that the overall mean is 5.20, which explained that the level of readiness of the public schools in terms of platform and support is much ready.

The availability of appropriate online platforms for student learning is still far from widespread in the world's education systems, according to Moreno (2020), but the good news is that most school principals are confident in their teachers' pedagogical abilities and the availability of tools to assist them in using digital learning while students are at home. It is important to ensure universal Internet access now, as this will enable schools to efficiently use EdTech in age-appropriate ways as part of their daily instruction. The goal is to make the transition to distance learning as painless as possible, allowing students to continue learning even if school operations are disrupted in the future.

\section{CONCLUSION}

Based on the findings of the study, the researcher concluded the following:

The level of school heads' leadership practices in terms of instructional directives, resiliency in stress management, management of conflicts, and establishing effective functional teams are highly practiced. The 
International Journal of Theory and Application in Elementary and Secondary School Education (IJTAESE), Vol. 3 (2), 156-170

School Heads' Leadership Practices in The New Normal, Administrative Disposition, and Readiness of The Public

Schools in Laguna

Rycel B. Villar, Alberto D. Yazon, Consorcia S. Tan, Lerma P. Buenvinida, Marcial M. Bandoy

level of school heads' administrative disposition in terms of commitment, honesty, inclusivity, and accommodative are very evident, while in empathy and tolerance, it is evident. The level of readiness of the school in terms of governance, content, and teacher's preparedness are very much ready while in terms of platform and support., continuance, assessment, learner's preparedness, and parent's preparedness are much ready. The null hypothesis stating that there is no significant relationship between the level of school heads' leadership practices and the readiness of the school was rejected. There is a significant relationship between the level of school heads' leadership practices and the readiness of the school in terms of the following:

a. Instructional directives along with governance and teacher preparedness.

b. Resiliency in stress management along with platform and support, governance, content, continuance, teacher preparedness, learner preparedness, and parent preparedness.

c. Management of conflicts along with governance, content, and teacher preparedness.

d. Establishing effective functional teams along with governance, content, and teacher preparedness.

The null hypothesis stating that there is no significant relationship between the level of administrative disposition and the readiness of the school was rejected. There is a significant relationship between the level of administrative disposition and the readiness of the school in terms of the following:

a. Commitment along with platform and support, governance, content, continuance, teacher preparedness, learner preparedness, and parent preparedness.

b. Empathy along with platform and support, continuance, learner preparedness, and parent preparedness.

c. Tolerance along with platform and support, continuance, teacher preparedness, learner preparedness, and parent preparedness.

d. Honesty along with governance, content, continuance, and teacher preparedness.

e. Inclusivity along with platform and support, governance, content, continuance, assessment, teacher preparedness, learner preparedness, and parent preparedness.

f. Accommodative along with platform and support, content, continuance, teacher preparedness, learner preparedness, and parent preparedness.

The null hypothesis is stating that the school heads' leadership practices and administrative disposition do not significantly predict the readiness of the school is rejected. The school heads' leadership practices and administrative disposition significantly predict the readiness of the school in terms of inclusivity, accommodative, and resiliency in stress management.

\section{Recommendations}

This study was delimited to the school principals in the City Schools Division of Laguna (Binan, Santa Rosa, Cabuyao, Calamba, and San Pablo). Since the school heads' leadership practices are significant predictors of readiness of the school, school heads may continue to prioritize regular and clear contact with subordinates to avoid disagreements and misunderstandings about school issues and concerns. School principals may cultivate a positive attitude and resiliency in the face of adversity, difficulty, and tension in order to effectively handle and resolve various obstacles that may obstruct the school process. To achieve excellent school learning results, school principals must establish a shared agreement with their subordinates in order to create successful teams and teamwork.

To ensure a more efficient school performance and learning outcomes, school principals may impose sustainability and enrichment of existing good practices. School heads may continue to practice their administrative disposition in terms of empathy. During this pandemic, school heads must have the ability to understand the needs of others and be aware of their feelings and thoughts since it is highly significant in the readiness of the school. School heads' leadership practices in terms of resiliency in stress management is one of the predictors of the readiness of the schools; the school governance operations development team thru Human Resource Development and DRRM may continue to provide training about resiliency in stress management during this pandemic so that the school heads may enhance their individual self-development and have an enormous bottom-line impact on entire organizations. 
International Journal of Theory and Application in Elementary and Secondary School Education (IJTAESE), Vol. 3 (2), 156-170 School Heads' Leadership Practices in The New Normal, Administrative Disposition, and Readiness of The Public Schools in Laguna

Rycel B. Villar, Alberto D. Yazon, Consorcia S. Tan, Lerma P. Buenvinida, Marcial M. Bandoy

For future researchers, other school heads' leadership practices about instructional directives, managing conflicts, and establishing effective teams may be studied along with different administrative dispositions that will enhance the readiness of the school during this new normal.

\section{REFERENCES}

Allisson (2016). The Resilient Leader

Brooks. (2016). School readiness in urban communities [Unpublished master's thesis]. Rowan University.

Cunningham, W. G., \& Cordeiro, P. A. (2013). Educational leadership: A bridge to improved practice. Prentice-Hall.

DepEd Order No. 13 s. 2020 also known as the Readiness Assessment Checklist for Learning Delivery Modalities. (n.d.).

DepEd Order No. 24 s.2020, National Adoption and Implementation of the Philippine Professional Standards for School Heads. (n.d.).

(n.d.). Discover Journals, Books \& Case Studies | Emerald Insight. https://www.emerald.com/insight/content/doi/10.1108/JPCC-06-2020-0045/full/pdf?title=covid-19school-leadership-in-crisis

DM 050, S. 2020 - DepEd professional development priorities for teachers and school leaders for school year 2020-2023. (2020, May 4).

Dockett. (2017). The Role of Schools and Communities in Children's School Transition. Murray School of Education, Charles Sturt University, Australia

Farmer, T. A. (2010). Overcoming adversity: Resilience development strategies for educational leaders. Georgia Educational Researcher, 8(1). https://doi.org/10.20429/ger.2010.080101

Fisher, W.P. Jr (2007). Rasch Measurement Transaction. Transaction of the Rasch Measurement SIG American Educational Research Association. Vol. 21 No.1, p. 1095

Framework for reopening schools. (n.d.). https://www.unicef.org/documents/framework-reopeningschools

Harris (2020) COVID $19 \quad-$ school leadership in disruptive times. https://www.tandfonline.com/doi/full/10.1080/13632434.2020.1811479

Helm. (2010). Article 21. Leadership Dispositions: What Are They and Are They Essential to Good Leadership, 8(1).

High/Committee on Early Childhood, Adoption, and Dependent Care and Council on School Health. (2016). School Readiness.

Humphrey, R. H., Burch, G. F., \& Adams, L. L. (2016). The benefits of merging leadership research and emotions research. Frontiers in Psychology, 7. https://doi.org/10.3389/fpsyg.2016.01022

Keith, T. Z. (2019). Multiple regression. Multiple Regression and Beyond, 195-225. https://doi.org/10.4324/9781315162348-10

McNulty. (2019). Distributed leadership requires the disposition of empowerment, not a position or title. www.naesp.org

Morgan L. (2015). The Influence of School Leadership Practices on Classroom Management, School Environment, and Academic Underperformance. https://scholarworks.waldenu.edu/cgi/viewcontent.cgi?article=1451\&context=dissertations

(n.d.). Centers for Disease Control and Prevention. https://www.cdc.gov/coronavirus/2019ncov/downloads/community/School-Admin-K12-readiness-and-planning-tool.pdf

Napire (2019). Adversity Quotient and Management Skills of School Principals: Their Influence on Institutional Performance. 
International Journal of Theory and Application in Elementary and Secondary School Education (IJTAESE), Vol. 3 (2), 156-170

School Heads' Leadership Practices in The New Normal, Administrative Disposition, and Readiness of The Public

Schools in Laguna

Rycel B. Villar, Alberto D. Yazon, Consorcia S. Tan, Lerma P. Buenvinida, Marcial M. Bandoy

Nelson, R. F. (2011). The school readiness school readiness of preschoolers from urban urban backgrounds. Transitions to Early Care and Education, 107-115. https://doi.org/10.1007/978-94-007-05739_10

Ogena, etal. (2020). Education Imperative for the New Normal: Planning for Flexible Learning.

Papantos. (2021). The Use of Tolerance in Effective Leadership. benedictine.university.online.https://online.ben.edu/programs/ba-management/resources/the-use-oftolerance-in-effective-leadership

Pearson and Spearman. (2018). Correlation and regression: Intermediate Statistics Using SPSS, 276307. https://doi.org/10.4135/9781071802625.n11

Pereira. (2019). Dispositions of Effective Principals of K-12 schools according to faculty of a school education.

Perez. (2015). Knowledge, Skills and Dispositions of School Principals: Perspectives from Kisumu County, Kenya, 1(3), 79-90.

Raney, A. A. (2006). The Psychology of Disposition-Based Theories of Media Enjoyment. In J. Bryant \& P. Vorderer (Eds.), Psychology of entertainment (p. 137-150). Lawrence Erlbaum Associates Publishers.

Raney, A. A. (2020). Affective disposition theory and disposition theory. The International Encyclopedia of Media Psychology, 1-12. https://doi.org/10.1002/9781119011071.iemp0175

Reading into stratified random sampling. (n.d.). Investopedia. https://www.investopedia.com/terms/stratified_random_sampling.asp

Republic Act (RA) 9155, also known as the Governance of Basic Education Act of 2001. (n.d.).

Reyes, Y. D. (2018). Teachers' and school administrators' perception on the strategic leadership practices of school administrators. The Educational Review, USA, 2(8). https://doi.org/10.26855/er.2018.08.004

UNICEF. (2012). SCHOOL READINESS: A Conceptual Framework.

Veland. (2012). A Study of Leadership Dispositions of Transformational Leaders in Georgia High School [Doctoral dissertation].

WHO (2020) The United Nations Educational, Scientific and Cultural Organization is a specialised agency of the United Nations aimed at promoting world peace and security through international cooperation in education, the sciences, and culture 